\title{
KINESTHESIA: THE CREATIVE CONDITION FOR HEALTH COMMUNICATION
}

\author{
Joseph J. PILOTTA (iD * \\ ${ }^{1}$ Ohio State University, School of Communication, 11800 Cannon Drive, \\ Columbus, Ohio, 43210, United States \\ ${ }^{2}$ Faculty of Creative Industries, Vilnius Gediminas Technical University, Vilnius, Lithuania
}

Received 11 October 2019; accepted 27 May 2020

\begin{abstract}
Kinesthesia is a universal condition. It may be understood as the creative condition for all sense and sensibility. Kinesthesia operates as an enabling mechanism of "I can" and "I cannot". Health communication requires a reconsideration of the situated communicative body and expression found in comparative East/West wellness practices. In order to accomplish this task, the exploration of whole and healthy require a different understanding, that is, that wholeness is a process of the interaction of body's internal environment and external environment in rhythmic interplay of healthy/unhealthy, wholly/unwholly play. The articulation of the above will see that kinesthesis is the creative condition of maintaining and restoring health. It is through a phenomenology of kinesthesia that the fundamental dimension of health communication can be established as a science.
\end{abstract}

Keywords: body, chi, communication, creativity, kinesthesis, tai chi, things, wholeness.

\section{Introduction}

There are social, cultural, and civilization diseases and illness. Globalization and the tech-orientation facilitate the causes and the effectuation of cure. There is a tendency to integrate Eastern and Western understandings of health, health practices, and medicine from the level of the individual to that of the corporation. Word such as sustainability, corporate responsibility, holism and ecological environment dominate the landscape, providing a tacit acknowledgement to our claim. In our daily meeting with others, we say, "Hello, how are you?" inquiring as to how are you doing today and saluting one's health as evidenced in the word field cluster of word origins.

The word origin of healthy emanates from a family of words: hale, hallow, heal, health, and holy, with health being "the state of the whole", and it also carries the idea of "unimpaired" and "inviolate", as in the Greek holos, the Indian sarva, "undamaged", Dutch heiland, meaning "healer", and it connects with Greek soter, as well as the family of kinship words in Lithuanian and Sanskrit: sveikas and svayata, as well as in the Arab phrase saha wa hana (Ayto, 1991).

${ }^{\star}$ Corresponding author. E-mail: joepilottaphd@gmail.com 
Within the terms of modern medicine, the state of making whole is a restoration of a person to wholeness. Holism in this light appears to be a cerebral attempt at a recovery of interconnections lost in the course of analysis in the process of making different connections - if you will, a whole equal to the sum of its parts. However, there is another side, as in the Greek holes, which means "the activity of the whole". In short, wholeness resonates cosmological sensibilities or worldly sensibilities.

If we take both sides of the geometry of parts/whole and critique the ontological status, we find what the gestalt called "the open whole", where the whole is both more and less at the same time. Perhaps we need to open this now to a discussion of a critical wholeness of first principles. It must be noted that the part/whole relationship is more dynamic than common thinking has it. Parts reciprocally relate both to each other and to the whole, and the whole is reciprocally related to each of its parts. The open whole admits, and its environment influences, dynamically reconfiguring the whole system. The very activity of the whole is kinesthetic. Sensibilities are not localized in specific locations on one body but are synesthetically integrated across the whole/body/world of things (Pilotta \& Adair McCaughan, 2012). Kinesthesia puts our senses and sensibilities into a rhythm/pulse/tempo:

"Bodily rhythm is motion on credit. Confidence and timidity, elation and depression, instability and insecurity, are all expressed in gait. The gait of a biped is balance alternated from one leg to the other. This balance permits variation in length, tempo, and direction of accent" (Straus, 1965, p. 245).

The experience of disruption of the rhythm is a distance of ease (dis-ease) to our present situation. A breakdown of physical well-being is alarming in the experience of disease - it turns our attention to a function that on good days, we take for granted. A healthy person does not ponder about breathing, seeing, and walking (Straus, 1965, p. 232). Such symptomology is often accompanied by social anxiety. Anxiety often creates an environment of a fear of something that results in a closing of future horizons (Pilotta, 2020).

In the most recent state of the art in health communication review, Kreps, co-founder of the Health Communication Division of the International Communication Association, writes:

"Health communication inquiry, today, is concerned with the important influences on people's health of both face-to-face interpersonal communication (in activities such as health care interviews, counseling sessions, health-education efforts, care coordination, and the provision of social support) and mediated communication (including the many uses of print media, television, film, radio, computers, and other technologies). In broad terms, two areas of health communication inquiry can be identified: Health care-focused communication research typically examines issues associated with the influence of communication on enhancing the quality, accuracy, and effectiveness of diagnoses, treatment decision making, treatment follow-up care, support, and endof-life care; health-promotion-focused communication research most often focuses on the design and evaluation of health-education and promotion campaigns through analysis of message design, communication channels, and other campaign strategies and practices" (2015, p. 1).

Health communication and its diverse settings for research are primarily methodological, focusing on linguistic utterances and concomitantly with attitude, beliefs, and other norma- 
tive methodological foci. However, this is only one modality of communication. In a more recent article, a critique is offered of the traditional approach to health communication with an appeal to the concept of embodiment:

"Traditional research methods reinscribe a mind-body dichotomy based on Cartesian philosophy that renders the body the possession of the self, as equated with the mind. Poststructuralists and materialist theorists [...] reject the metaphor of the body as a container of the self $[. .$.$] . Embodied [...] research integrates body, mind, and spirit,$ resisting Cartesian dualism [...]" (Ellingson, 2019, p. 2).

Our focus on kinesthesis takes another major step, which is the creative condition for the critical concept of embodiment to be deployed.

\title{
1. Rhythmic movement
}

The moving body makes visible the very environmental terrain and mood of the body, revealing one's world:

\begin{abstract}
"Customary walking of Japanese compared to European from the 12th to the mid20th century had decidedly different comportments. Europeans walk from the hips while keeping legs straight. Japanese traditionally walked from the knees with a type of shuffle not unlike a person who lost their laces and tried to walk and hold on to their footwear. Walking from the knees is very effective for rough and hilly terrain as we may have experienced. The lower center of gravity reduces the risk of falling and tripping. This is ergonomically consistent when one is used to carrying heavy loads suspended from long supple poles resting on the shoulders" (Ingold, 2004, p. 325).
\end{abstract}

These differences can be seen across traditional dance styles, artisan techniques, and child rearing practices by the affirmation of the ground. If you will, there is a dialogic movement with the ever-changing environment and changing conditions of our unfolding of different tasks. We may say there is an intelligence in the sensory reading of the situation which is distributed through the whole field of relations comprising the human being by inhabiting the world in which one lives.

In the Chinese world, there are only the passing circumstances in which things dissolve into the flux and flow of their surroundings. Things are not objects but rather foci within a continuous field of changing processes and events (Ames \& Hall, 2010, p. 10). The attentional field expresses a world always in flux in which items cannot be fixed, passing into other, correlated states. This is no final whole, but rather an interactive field. Qi/chi may be conceptually called a vital energy field. Discriminations in the field of $q i$ are made in terms of observed and conventional classifications associated with diurnal and seasonal changes, directions, colors, body, and so forth. Habits are the structures of what makes up mediated and unmediated experience. In the Chinese world things do not have habits; things are habits. $L i$, ritual propriety, is a habitual behavior of "to be present", or "making present the past". $L i$ depends on relationships and processes with a focus on the familiar and creates a communication community. $Q i$ is an animal/animate/animus of a vital energy field with focal manifestation, transforming of process, and transformation.

Creativity for the Chinese is a notion that can be characterized in terms of self-actualization. Creativity as a process has no outside force, no separation or distancing, nothing 
to overcome (Ames \& Hall, 2010, p. 12). It is a spontaneous production of novelty that is always reflexive and is exercised in respect to the self. Creativity is always social, cultural, and dialogically co-creative. All creative processes render self-cultivation as self-creation. In a process world, it is one of mutuality by a field of actualized selves, each a focus of transactional realization. (As an aside, the Chinese language is a gerundive language, which points up the multidimensional character of the creative process (Ames \& Hall, 2010, p. 37)). It is within this vein that we may refer to wholeness as a creative process which can be understood as integrity. Hence, creativity is a becoming whole; becoming whole is viewed aesthetically and practically.

Creativity is both the realization of the focal self and of the field of events, the realization of both the particular and the context. The field and focus are reciprocally realized. Integrity is effectively integrating one's social and cultural contexts. At a cosmological level, integrity is the ground from which self and others arise together in mutual benefit. It is not what things are, but how well and how productively they are able to fare in their synergistic alliance. Such a commitment to integrity is their process of becoming whole and healthy. The creative endeavor is the element of affirming things as they are and participating in the process of drawing out novel possibilities from the circumstances. In order to activate body realignment, the activation of sedimented habits, or how it feels and how we can move, becomes the possibility for alternative body alignment.

\section{The body human}

The above understanding of the body, of things, and of ourselves is, in our conventional wisdom, relatively foreign to our Western conceptualization of theory and method. (Conventional wisdom being that social behavior and medical behavior do not accommodate the integration of bodily self-experience of health and illness.) This lack of investigation across the multiplicity of cultural and civilization settings, retards changes in policies regarding both health prevention practices and medical cure and curating. Our disciplines are essentially disembodied spectacles based on several assumptions regarding the equalization of the social significance of the human body. The medical paradigm of the body a bio/mechanical model:

1. Organs are anatomical and location based;

2. European conceptions of the body focus on the experience of tension (tonus).

Tension is crucial for our ability to see and hear. Strenuous exertion in European modes of exercise, aimed to maintain and improve muscular and physical tone, remain different from those of China. European tenseness and looseness are distinct from Chinese fullness and depletion. This leads to different feelings about life (Pilotta, 2020). In order to complement and or integrate the dominant assumptions, we need to look at the situated body.

\section{The situated body}

The situated body is a sensuous body - a wholly body - which serves to circumscribe a communication paradigm based upon concrete corporeity. This means that body limits emerge when humans shape their environment in accordance with specific aims. 
Corporeal intentionality becomes essential to the kinesthetic of universal health. It is also possible that, through preparation and training, one can awaken one's motor abilities of one's own body through living - in the awareness from within. This is done by restoring body reflexivity at the heart of body intentionality. Merleau-Ponty (1962) opens a domain of bodily engagement with the world that is both situational and accessible (universal).

It must be noted that the oriented, practical body functions in a way that the directions are not completely exchangeable. What is up front, reachable by a forward movement, is distinct from what is in the back, and the latter is present, as are its rules and concepts and compacted, overlapping ambiguous field meanings. Space consists of indifferent points that cannot be assigned such meanings as here-there, up-down. These points are the condition for the possibility of structuring and communicating a world of places and locations, up-down, right-left, forward-backward (Pilotta \& Mickunas, 1990, p. 168).

These indices carry with them terminology such as status, hierarchy, and in politics, right and left, just as turning/spiraling is an original movement of the unfolding of the these polar or dualistic orientations.

Linguistic rules, prescripts, and prejudgments make sense in a situation because the situation itself is not a brute fact, but rather it traces a corporeal generality which is not quite in accord with the purity of conceptual constructs, but which is not idiosyncratically singular either. The acting body can be loosened up or tightened for a focused task; it can approximate but never reach the conceptual ideal, and thus it can open up the ideal to variations. An activity toward a goal can limit itself to very select means and a narrow interpretation of the goal, or it can relax and regard the means as fluctuating and the goal open to various temporal horizons. The lived body, as a situation, allows for the tightening and loosening of the situation and hence the establishment of a flexible space and time - both for itself and for the phenomena with which it is involved.

It must be emphasized that the differentiation which forms perceptual meaning is not introduced by a subject, but rather is always a field function, a pregnant origin. To bring forth a figure on the background perception is productive insofar as it traces what is available in the pregnancy of the field. This field genesis entwines activity and passivity, and the recipient discovers and equally traces what is already inscribed in the perceptual field, thus discarding the primacy of the subject. The figure that emerges with perception is not a determinate phenomenon but a vector of the world on whose pivot other vectors are equally intertwined and communicated. In this sense, while tracing and communicating a vector, we also are dispossessed of the more in the field, and we can be challenged by others concerning our inadequacy in providing a totalizing picture.

This is the source of communicative creativity that cannot be closed by any grammar or accustomed categorization that presume fixed meanings. We speak of seeing "black" and "white" and even attach cultural terms to them such as "good" and "evil" or "light" and "dark" and extend such fixed meanings to all sorts of light metaphors, such as "in light of pure reason". These categorical conveniences cannot pretend to be representations of our perceptual experience. It is physically impossible to see black or white; perceptually we shiny, vibrant, dull, somber, crumbling, ruffled, or impenetrable, wherein no such "black" in itself ever appears. The same can be said of all the colors in the so-called spectrum. 
Moreover, such perceptual richness cannot be accounted for by metaphoric language or some form of analogization. Analogies, likenings, are aspects of practical communication between bodily activities and the world. In face of a task, such as aerobic exercise, one searches for appropriate means to perform such a task. One may pick up a soup cans, stones, or vegetables in order to flex with mild resistance. Here, the categorical distinctions between stones, cans of soup, and vegetables move into the background, where each becomes an analogue of the other through the exploring hand and eye. It can be contended that most of our tasks are performed by bodily activities engaged in analogical awareness. Hence, our accustomed communication, based on historically accumulated language, is interrogated by the phenomenal field. The world speaks a silent and meaningful language that no coded language can adequately capture.

It is a field of sedimented meanings that inhabit the very phenomena of perception. Moreover, language forms its own density in which meaning remains embedded as an indefinite difference among accumulated differences. Linguistic meaning resists complete clarity of expression, and thus, language as such can never be made an object of exhaustive analyses by some "meta-language" and its formal rules. Within the density of language, sedimented meanings form a crust that resists the spontaneity of perceptual engagement and the creative language. One could say that such a crust forms a surface discourse that has lost its creative and interrogative origins in perceptual life.

Sedimented language is well-suited to overlap with sedimented body activity that becomes anonymous. As a body inhabits a particular task, attention must be directed to specific functions that relate to specific aspects of the environment. While learning how to drive a car, one must shift gears, press pedals, steer the wheels, watch the traffic, read signs, listen to music, talk on speakerphone, and use voice-to-text. Within a brief period, one settles into the functions of the car and assumes a sedimented body of a driver who is completely geared to all functions of the car and all structures and shifts in the environment. The body becomes the "habit" of the car, as it can also become the habit of an apartment where there is no need to deliberately look for places or things.

Indeed, sedimented language overlaps very easily with body habits and its communicative meanings are taken for granted. Such sedimented bodies are the very fabric of cultural communication. The rituals we perform, walking styles, dancing, shopping, are cultural body styles. There is no cultural or cross-cultural communication that would be "disembodied". It is equally important to stress that sedimented and encrusted layers of comportment and speaking do not determine perceptual awareness absolutely; they are always loosened by perceptual horizons and depths and thus obtain a character of creativity. Participation in communication is a creative venture, and it is always a practical and engaged venture where language and perceptual meanings overlap. Language and perceptual meanings overlap with another communicative and all-pervasive experiential domain: being bodily as expressive communication.

\section{The body reflexive - knowing while doing: integration of East and West}

Chinese tai chi offers a model of becoming whole. It has been shown to improve aerobic capacity, blood pressure, reduce stress, increase strength, facilitate better sleep patterns, and so 
on. The benefits were shown to be memory regeneration, improved gait, improved flexibility, and the rejuvenation of connective tissue (Sharp \& Hewitt, 2014). It is interesting to note that tai chi is often seen as an exercise more than as falling within the framework of martial arts. In fact, tai chi was originally part of a dance ritual. Tai chi draws its power from what we might call a "figure eight" movement, which has strategic pauses or apostrophes which allow for the next movement possibility. It is a slow, concentrated explosion, a numinous power. Topologically, tai chi reveals the cosmology of the Yin/Yang, "figure eight," or the Möbius of meditative dance:

"Life is a system of the cyclic upward and downward movements, and these movements are related to energy flow. In this process of change, movements associated with the transforming effect are called yang while those contributing to structure are called yin. Yin is downward, and yang is upward. Yin is passive; yang is active; yin is quiet; yang is restless" (Herfel et al., 2007, p. 61).

"When the systems of the body oscillate harmoniously with the environment and the internal oscillations within the body are harmonious, the organism is healthy. Harmony in this context means that the patterns observed reveal that the elements of the system stand in the right dynamic interrelations" (Herfel et al., 2007, p. 63).

Working on strengthening, stretching and body realignment is to keep one from freezing in one's gait. We suggest that there are effective blockages which create patterns of muscular tensions in a body attitude of a somatic nature. Relaxation and ease of movement are keys to the openness, balance, and stillness. The stillness is an intensity of gesture applied to the balance of walking, before placing the foot to the ground and the weight being shifted from one side to the other. The balance provides the weighting with the stabilizing in each step. In turn, it allows for synchronization into patterns of rhythm and timing. A "rooting" requires both feet on the ground; then grounding is a pregnant pause, creating breathing from the abdomen, not from the upper chest. In principle, tai chi offers access to an alternative embodied style of operation. Entering into this alternative requires a kinesthetic activity.

\section{Circularity of movement}

The opening/closing exchange is known as the pulsing opening and closing - the alternating rhythm of expansion/condensing which may miss the opening and closing techniques which focuses on the "in" space between the joints of hands, wrists, elbows, and other cavities such as armpits. Tissue stretching focuses on the back and outside surfaces. This relaxation creates a looping of energies and focuses on helping the immune system and its defense mechanisms.

The pace of the foot experience is floating, lightness and the experience of a rippling effect. The stretch is the interconnection of movement intention in relationship with a single pass activating the sympathetic nervous system's relaxation and then activating the parasympathetic nervous system. One's deep breathing, inhaling, relaxation demands the oxygenation of the blood circulation, which in turn activates tissue regeneration for an internal healing. We are stressing the body and the internal awareness of Chinese martial arts through the power of stillness. In stillness, the state of being is a pregnant set of possibilities for movement. Our posture can be seen as a type of movement stillness. A standing meditation, entailing as a readiness per se, enabling us to respond to an environment rather than to react to it. 
Because our bodies are multidimensional, our movements are degrees. When one rotates along the sagittal plane, for example, one is engaging by extension to keep upright, and what is happening is initially a spiral form. The Chinese skeleton is bearing the flesh and blood; described as the process in which the entire body, including the gaze, is concentrated in a series of movements.

The body, breathing deeply and slowly summoning, as if one were connected to a great lung outside of oneself. Its alternation calls to enforce backup to one's breast rhythm of respiration and movement (Merleau-Ponty, 1962, p. 53). Breath inhabits, inhales and exhales corporeally over a world within us. Conversely, we might indicate that this, in the philosophy of communication, resides in the rhythm of restoration. In fact, Western civilization has been inspired by Promethean perspiration, whereas Eastern civilization is inspired by respiration.

\section{Body with self}

When we touch our bodies, the sense that we are living in the touching hand can dominate. I can touch myself in much the same way as I might palpate another person's body, feelings structure (tonus), movement, resistance, and so forth. Conversely, I can give myself over to being touched, receptive to touch from me in the same way I could receive it. This is a co-mingling of touch/touching. This is probably most helpful to our understanding of the conditions for tai chi success with neuro-muscular diseases. For instance, I can consciously harmonize my body by walking in an asymmetrical way, as many neuro-muscular sufferers do as a normative posture. It is possible the feeling may emerge; this is a basic understanding of how to format the ground. Some figurations can be harmonized by finding an asymmetrical posture which one may find oneself in; for example, one finds out the leg "goes to sleep" or a foot is sore, and so forth, outside of one's habitual awareness, making the harmony more difficult.

Being "stuck" is a way of describing behavior of "freezing" and motility-awareness strikes. It should strike the reader that harmonizing is a way of reinterpreting what is happening to or in me or "inside" me, not only by feeling my way into it, but also experiencing whatever is going on "as if it is I myself doing". (Of course, there are limits.). The harmonizing of the body relies upon a creative element of our body which is always with us.

However, there's another way that embraces oneself or others' disability: body reflexivity. We may harmonize with the other body's mobilization as the way it is and it becomes a possibility. Something that is given as simply actual, is maintaining a "being this way". But the act of consciously maintaining it becomes a possibility which can be actualized "here and now". The transformation of the conditions into a possible among other possibilities are as thinkable and doable in the very present. Instead of presenting the treatment or corrective, we are prescribing the manifestation of dis-ease surrounding the actual and other possible ways to be. Harmonizing is a way of participation predicated as a tendency towards a healthy body, and it encourages autonomy and responsibility without tearing the individual from his/her context. 


\section{Awareness of chi}

Chi moves in two basic directions which we can call ascendency - which equalizes to a spreading movement of chi, i.e., up and out, and descending - meaning the sinking and inward gathering of chi. In simple terms, it is moving or resting, yang or yin respectively. When we practice tai chi, we are moving toward the surface and using our (intent) to maintain an outward direction for our energy flow. If we persist in this and do not spend time with the setting when performed correctly, it has a beneficial effect over the whole of the energy and energy information of the body. The aim of chi is to allow breath and movement to synchronize.

In Chinese medicine, the pulses of the body are used as a diagnostic tool. In Western medicines, the pulse is indicative of good heart blood flow. In Western medicine, there is one pulse; in Chinese medicine, there are 29 pulses, giving clues to different organs in the body and their interrelationship so the practitioner can discover the imbalance in the body. Each organ has its own pulse or beat: floating, surging, soft, slow, leathery, tympanic, slippery, knotted, bound, rolling, intermittent, rapid, skipping, throbbing, and so forth. Pulses create rippling effects throughout the body, making apparent the internal and/or external manifestation of the environment. The rhythmic movement of pulsing reveals the world of the individual and the concentric circles of guanxi (family, friends, classmates, business associates).

We should note that movement dynamics prior to differential are consistent with the mode of ascending/descending flowing and sinking. The cosmos resembles the movement of spiraling and the forceful position of a "coil" or "coiling over". Transparency occurs through breathing, gesture, and gestation of tai chi practice. The body organs are transparent with kinesthetic color appearing through dissipation and absorption as in breath.

The insistence on the open air-like and even negative elements within the body also open in a most cosmic tone. The breathing rhythm reflects within the body the movement of wind through the world, manifesting itself as a reflection between visible and invisible. Breathing is an inter-referring phenomenon that is a situation in heterogenetic elements which are, at the same time, divided and connected. It relates to the lungs, bronchi, trachea, nose, and mouth, but also some times air, which would seem to be excluded in such a connection. Breathing is movement with its obvious practical significance, it cosmological significance, and its involuntary movement can be reflexively controlled and reconfigured for altering one's physiological system. The alternation of breathing is and has been creatively used to overcome anxiety, stage fright, singing, and other stressors in one's life.

\section{Conclusions}

The above phenomenological explication of the creative condition of kinesthesis with tai chi is a model for integrating Eastern and Western orientations to Health Communication as a scientific discipline and for practical orientations to wellness and medicine. In terms of holistic practices [spelled W(holistic)], the dualistic assumption of the West and polar elements of the East become an integrity which is both and more than either. In order to achieve the needed health communication science, we must understand health communication as 
a sensuous science, and some of the truths therein. These truths have been attended to in a previous work.

The sensuous kinesthetic body is a universal which is formal and general and which remains invariant in the lived world throughout all alterations of the relative. The sensuous universal is the invariant form of all world-lives and world-views, and reveals the essence of all communication theory and all social science - the comparative. The sensuous universal is the condition which allows the exchange of information between specialists and the lay public.

All human sciences are comparative sciences:

"[W]hat allows comparison is specifically the fact that everyone who has a world is limited. Limits are a transcendental condition for people having different cultures, and they are the condition for different cultures to have something in common. The invariant in all conceivable worlds must be present as something which is shared before all differences of particular worlds. This invariant must be that which is the beginning of all communication" (Pilotta \& Adair McCaughan, 2012, p. 283).

The sharing is a harmony of the functional bodies.

The essence of corporeity is nothing less than a system of functions, not merely a physical body. One must be cognizant of the presupposition of the general sign of life as selfmovement. Functionalities are generalities which lay the foundation for the comprehension of the meaning of a situation - intersubjectivity and individuality as inseparable correlates.

The functional body is a "passive domain" and is different from the physiological body. The difference is:

1. The priority of the function of practical experience;

2. The possibility of understanding the physiological rests on the change derived from the practical experience (Pilotta \& Adair McCaughan, 2012, p. 260):

"[...] [and] our activity is directed by symbolized sensibilities, yet we express an original or "creative" relationship to things by following the lines of implication, which point to new perspectives and our self-understanding. In our view, the sensuous universal is an evaluative criterion for social progress" (Pilotta \& Adair McCaughan, 2012, p. 268).

For health communication to be a true communication science, we must rethink the body as a creative body of kinesthetic sensibilities while integrating the symbolic sensibilities of different civilizations and cultures.

\section{References}

Ames, R. T., \& Hall, D. L. (2010). Focusing on the familiar: a translation and philosophical interpretation of the Zhongyong. University of Hawaii Press.

Ayto, J. (1991). Bloomsbury dictionary of word origins. Bloomsbury Publishing.

Ellingson, L. L. (2019). Embodied methods in critical health communication. Frontiers in Communication 4. https://www.frontiersin.org/articles/10.3389/fcomm.2019.00073/full

Herfel, W., Rodrigues, D., \& Gao, Y. (2007). Chinese medicine and the dynamic conceptions of health and disease. Journal of Chinese Philosophy, 34(1), 57-79.

https://doi.org/10.1111/j.1540-6253.2007.00453.x 
Ingold, T. (2004). Culture on the ground: the world perceived through the feet. Journal of Material Culture, 9(3), 315-340. https://doi.org/10.1177/1359183504046896

Kreps, G. L. (2015). Health communication inquiry and health promotion: a state of the art review. Journal of Nature and Science, 1(2). http://www.jnsci.org/files/article/e35.pdf

Merleau-Ponty, M. (1962). Phenomenology of perception. Series: International Library of Philosophy and Scientific Method. T. Honderich (Ed.). Routledge \& Kegan Paul.

Pilotta, J. (2020). Tuning In: Tai Chi as Mythotherapeutic Practice. In Z. Zagaris (Ed.), Preeminence of myth and the decline of instrumental reason. Nova Publishing.

Pilotta, J. J., \& Adair McCaughan, J. (2012). The sensuous difference: from Marx to this... and more. Hampton Press.

Pilotta, J. J., \& Mickunas, A. (1990). Science of communication: its phenomenological foundations. Series: General Communication Theory and Methodology. Laurence Erlbaum Assoc Inc.

Sharp, K., \& Hewitt, J. (2014). Dance as an intervention for people with Parkinson's Disease: a systematic review and meta-analysis. Neuroscience and Biobehavioral Reviews, 47, 445-456.

https://doi.org/10.1016/j.neubiorev.2014.09.009

Straus, E. W. (1965). Born to see, bound to behold: reflections on the function of upright posture in the esthetic attitude. Tijdschrift voor Filosofie, 27(4), 659-688.

\title{
KINESTEZIJA: KŪRYBINĖ SVEIKATOS KOMUNIKACIJOS SĄLYGA
}

\author{
Joseph J. PILOTTA
}

\section{Santrauka}

Kinestezija - tai universali būklè. Ji gali būti suprantama kaip kūrybinẻ visų pojūčių ir visų jausmų sąlyga. Kinestezija veikia kaip funkcijų „Aš galiu“ ir „Aš negaliu“ derinimo mechanizmas. Sveikatos komunikacija reikalauja iš naujo apsvarstyti komunikuojančio kūno būklę ir raišką, aptinkamą lyginamosiose Rytų ir Vakarų sveikatingumo praktikose. Siekiant atlikti šią užduoti, visumos ir sveikatingumo tyrimą reikia suprasti kitaip: vientisumas - tai vidinès kūno terpès ir išorinès aplinkos interakcijos procesas, vykstantis ritmiškos sveikatingumo / nesveikatingumo, visumos / nevisumos sąveikos žaismo sąlygomis. Minètų dalykų pabrěžimas atskleidžia, kad kinestezija - tai kūrybinè sveikatos palaikymo ir atkūrimo būklè. Remiantis būtent kinestezijos fenomenologija, sveikatos komunikacija gali būti pozicionuojama kaip mokslas.

Reikšminiai žodžiai: kūnas, či, komunikacija, kūrybiškumas, kinestezija, tai či, daiktai, vientisumas. 